See discussions, stats, and author profiles for this publication at: https://www.researchgate.net/publication/333337626

\title{
Penelitian Pendahuluan Mengenai Desain Pembelajaran Terkait Berpikir Kombinatorial
}

Conference Paper · May 2018

CITATIONS

0

2 authors, including:

Iden Rainal Ihsan

Bandung Institute of Technology

13 PUBLICATIONS 3 CITATIONS

SEE PROFILE

Some of the authors of this publication are also working on these related projects:

Bilinear Spaces, Algebra on Mathematical Music Theory, Algebraic Coding View project 


\title{
Penelitian Pendahuluan Mengenai Desain Pembelajaran Terkait Berpikir Kombinatorial
}

\author{
Iden Rainal Ihsan ${ }^{1, a)}$, Usep Kosasih ${ }^{2}$ \\ ${ }^{1,2}$ Pendidikan Matematika, Universitas Islam Nusantara, Bandung \\ ${ }^{a)}$ E-mail: irainalihsan@uninus.ac.id
}

\begin{abstract}
Abstrak. Latar belakang penelitian ini adalah kesulitan mahasiswa dalam menyelesaikan beberapa permasalahan kombinatorika, dalam hal ini khususnya masalah pencacahan. Di lain pihak, peneliti memandang berpikir kombinatorial sebagai suatu kompetensi yang penting untuk dioptimalkan (dikuasai semua tingkatannya). Penelitian ini merupakan suatu penelitian desain (design research) dengan tujuan untuk merancang dan mengembangkan suatu desain pembelajaran kombinatorika (draf desain awal) yang dapat mengatasi kesulitan dan mengoptimalkan kemampuan berpikir kombinatorial mahasiswa. Tahapan design research yang dilakukan pada penelitian ini hanya tahapan penelitian pendahuluan (preliminary research). Pada tahapan tersebut peneliti melakukan analisis kebutuhan dan konteks, telaah literatur, dan proses pengembangan kerangka konseptual dan teoritis yang dalam hal ini perancangan dan pengembangan desain pembelajaran. Desain pembelajaran yang merupakan hasil dari penelitian ini berupa pembelajaran berbasis tugas. Secara umum desain yang diperoleh adalah kegiatan pembelajaran yang diawali dengan review konsep atau materi terkait, diskusi kelompok, proses penyimpulan, tes formatif, dan pemberian tugas mandiri.
\end{abstract}

\section{Pendahuluan}

Sebagai individu yang diproyeksikan menjadi pendidik mata pelajaran matematika, mahasiswa pendidikan matematika diharapkan memiliki beberapa kompetensi yang mumpuni. Salah satu kompetensi yang harus dimiliki mahasiswa pendidikan matematika adalah kompetensi profesional. Seorang pendidik mata pelajaran matematika haruslah menguasai semua materi atau konsep matematika, khususnya yang akan diajarkan kepada peserta didiknya kelak. Dengan penguasaan materi atau konsep matematika yang mumpuni sudah barang tentu seorang pendidik matematika dapat mengajar peserta didik dengan lebih percaya diri dan minim kesalahan, bahkan sangat mungkin tanpa kesalahan dalam penyampaian konsep atau materi.

Selain hal terkait materi atau konsep matematika, mahasiswa pendidikan matematika juga harus menguasai cara berpikir dan kecakapan matematis dalam mempelajari dan menyelesaikan persoalan-persoalan matematika yang kelak harus dapat diajarkan kepada peserta didik. Ihsan dan Kosasih [1] menyatakan bahwa salah satu kemampuan yang harus dimiliki oleh peserta didik adalah berpikir tingkat tinggi (higher order thinking skill/HOTS). Dengan demikian mahasiswa pendidikan matematika dipandang perlu menguasai HOTS.

Seorang pendidik penting untuk memahami HOTS. Dengan pemahaman yang baik mengenai HOTS, terdapat pengaruh yang signifikan bagi pendidik dalam mempersiapkan materi bagi peserta didik (Radenbush dalam [2]). Dalam pembelajaran matematika, terdapat beberapa permasalahan yang dapat mengukur tingkat HOTS peserta didik. Permasalahan yang dimaksud adalah masalah yang non-algoritmik, cenderung kompleks, open-ended, dan memerlukan usaha untuk menemukan struktur dalam ketidakaturan [2].

Di tempat peneliti bekerja, terdapat beberapa mata kuliah yang diminati oleh banyak mahasiswa, salah satunya kombinatorika dan graf (KG). Secara umum, setiap mata kuliah yang ditawarkan di tempat peneliti bekerja disusun sedemikian sehingga relevan untuk melatih HOTS mahasiswa. Namun demikian, peneliti menaruh perhatian khusus pada mata kuliah KG. Peneliti kedua adalah pengampu mata kuliah KG selama enam tahun ajaran berturut-turut sampai dengan tahun ajaran saat ini. Beberapa temuan penting menjadi latar belakang penelitian ini, salah satunya 
adalah kesulitan mahasiswa dalam menyelesaikan permasalah-permasalahan. Dari hasil refleksi, survey, dan wawancara yang dilakukan setiap akhir semester, peneliti kedua mendapatkan suatu temuan yakni kesulitan mahasiswa dalam menyelesaikan masalah dikarenakan rendahnya HOTS yang dimiliki oleh sebagian besar mahasiswa.

Peneliti memandang perlunya disusun suatu desain pembelajaran yang dapat melatih HOTS mahasiswa, tertutama dalam mata kuliah KG. Perlu disusun suatu desain pembelajaran yang dapat mengarahkan mahasiswa untuk dapat menganalisis masalah-masalah yang bersifat khusus dan sederhana untuk kemudian menemukan dan memahami konsep-konsep yang cenderung lebih kompleks. Dengan kata lain diperlukan suatu desain pembelajaran yang dapat memfasilitiasi mahasiswa berpikir mulai dari hal yang sederhana untuk kemudian dapat berpikir lebih kompleks.

Lockwood [3] menyatakan bahwa kombinatorika penting untuk diajarkan karena kaya akan potensi untuk mengajarkan proses dalam memecahkan masalah. Lockwood melanjutkan bahwa kombinatorika penting untuk diajarkan karena aplikasinya diberbagai bidang, diantaranya ilmu peluang dan ilmu komputer. Peneliti memandang perlunya suatu kemampuan yang dimiliki mahasiswa untuk menyelesaikan masalah-masalah kombinatorika, dalam hal ini masalah-masalah pencacahan. Rezaie dan Gooya [4] mengategorikan kemampuan berpikir kombinatorial menjadi empat level (tahapan). Level atau tahapan yang dimaksud [4] adalah tahap investigasi kasus, tahap justifikasi, tahap perumuman, dan tahapan terakhir adalah menyelesaikan masalah yang serupa. Level atau tahapan tersebut peneliti jadikan acuan utama dalam adalah membuat desain pembelajaran.

\section{Metodologi}

Penelitian ini dilakukan di tempat peneliti bekerja dengan fokus penelitian pada desain pembelajaran materi pencacahan (counting) mata kuliah KG. Penelitian ini merupakan suatu design research yang merujuk pada Plomp [5]. Berdasarkan rujukan tersebut, tahapan yang dilakukan peneliti hanya tahap preliminary research yakni menganalisis kebutuhan dan konten, telaah pustaka (studi literatur), dan proses pengembangan konseptual dan teoritis. Berikut ini adalah gambar mengenai tahapan (fase) pada design research sebagai studi pengembangan menurut Plomp [5]

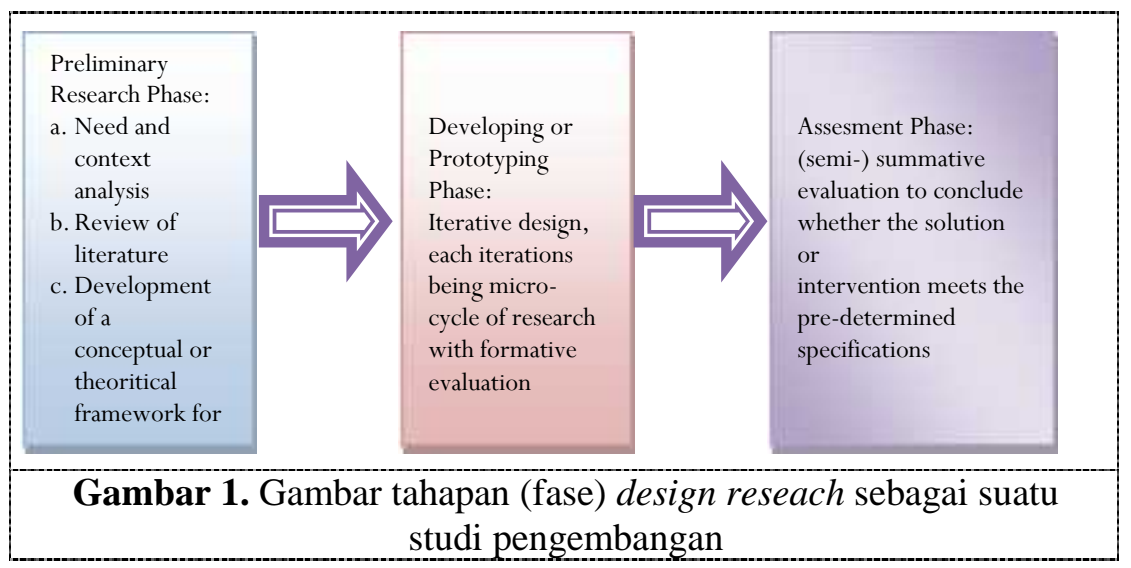

Pada sub tahapan analisis kebutuhan dan konten, peneliti menelaah kembali dokumen kurikulum mata kuliah kombinatorika dan graf. Peneliti menganalisis kebutuhan pembelajaran berdasarkan capaian perkuliahan (CP) yang termuat pada rencana pembelajaran semesteran (RPS) yang termuat pada [6]. Selanjutnya, masih pada sub tahapan yang sama, peneliti menganalisis konten pembelajaran materi pencacahan yang dikaitkan dengan konsep berpikir kombinatorial Rezaie dan Gooya [4]. Untuk memperkuat analisi konten, peneliti menelaah kembali beberapa pustaka terkait berpikir kombinatorial (Rezaie dan Gooya, Lockwood [3][4]) dan konsep-konsep pencacahan (Herman, dan Bryant [7][8]). Peneliti juga mengkaji konsep pembelajaran berbasis tugas yang dikemukakan Willis [9] dan konsep mengenai desain pembelajaran penemuan terbimbing Ihsan \& Iskandar [10]. Setelah telaah (studi) literatur selesai, peneliti kemudian 
melanjutkan ke tahapan pengembangan kerangka berpikir yang diwujudkan dalam proses penyusunan desain pembelajaran.

\section{Hasil dan Pembahasan}

Pada penelitian ini diperoleh suatu hasil berupa desain pembelajaran mata kuliah kombinatorika pada bagian bahasan pencacahan. Desain yang dimaksud merupakan desain awal yang pada tahapan design research selanjutnya akan diuji dan dikembangkan. Pada bagian ini akan dipaparkan penjelasan mengenai strukturdesain pembelajaran yang menjadi temuan pada penelitian ini. Struktur yang dimaksud terdiri dari kegiatan awal, kegiatan ini, dan kegiatan akhir.

Desain pembelajaran yang diperoleh adalah pembelajaran berbasis tugas (task-based learning/TBL). Komponen TBL yang dipergunakan merupakan modifikasi komponen TBL menurut [9]. Ada pun komponen TBL pada penelitian ini adalah sebagai berikut

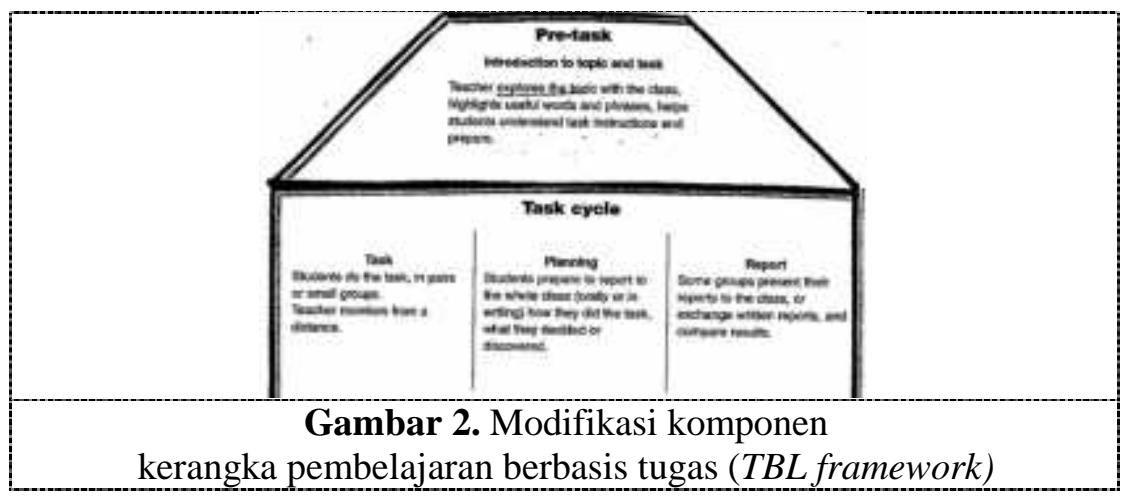

Peneliti juga menambahkan konsep self refelection [10] pada bahasan pembelajaran penemuan terbimbing. Adapun langkah-langkah kegiatan pembelejaran yang dimaksud adalah sebagai berikut

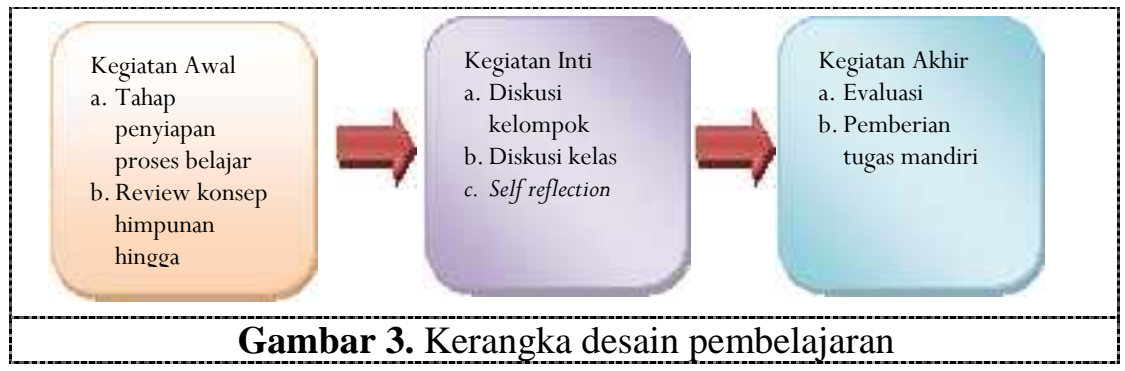

\subsection{Kegiatan Awal}

Pada kegiatan awal, perkuliahan diawali dengan penyiapan kegiatan pembelajaran dan review materi prasyarat terkait. Hal tersebut dilakukan untuk memberi suatu gambaran umum kepada setiap mahasiswa tentang konsep yang akan dipelajari pada kegiatan pembelajaran. Pada materi pencacahan, desain yang peneliti susun sebagai kegiatan awal adalah peninjauan kembali konsepkonsep himpunan hingga. Konsep himpunan hingga peneliti pilih karena kesesuaian dan keterkaitannya dengan materi-materi pencacahan. Pada kegiatan pembelajaran konsep aturan penjumlahan, konsep himpunan berhingga yang peneliti pilih adalah konsep mengenai sistem sub himpunan dari suatu himpunan berhingga. Misalkan $\left\{\mathrm{A}_{1}, \mathrm{~A}_{2}, \ldots \mathrm{A}_{\mathrm{n}}\right\}$, dengan $\mathrm{n}$ adalah bilangan asli, adalah sistem dari himpunan hingga $\mathrm{A}$ sedemikian sehingga semua subset yang dimaksud disjoin satu dengan yang lainya. Pada tahapan ini disampaikan persamaan sebagi berikut

$$
|A|=\left|A_{1}\right|+\left|A_{2}\right|+\ldots+\left|A_{n}\right|
$$

konsep tersebut yang peneliti gunakan untuk menyampaikan konsep aturan penjumlahan.

Berlanjut kepada konsep aturan perkalian. Konsep himpunan berhingga yang peneliti gunakan adalah konsep hasil kali kartesius. Misalkan $\mathrm{A}_{1}, \mathrm{~A}_{2}, \ldots \mathrm{A}_{\mathrm{n}}$ adalah himpunan-himpunan hingga, 
dengan $\mathrm{n}$ anggota bilangan asli. Dengan demikian kita miliki

$$
\left|A_{1} \times A_{2} \times \ldots \times A_{n}\right|=\left|A_{1}\right| \cdot\left|A_{2}\right| \ldots\left|A_{n}\right|
$$

konsep tersebut peneliti gunakan sebagai permulaan kegiatan pembelajaran konsep aturan perkalian.

Pada pembelajaran konsep permutasi dan kombinasi, peneliti memilih untuk menyampaikan mengenai telaah ulang mengenai konsep himpunan hingga terkait pembelajaran mengenai aturan penjumlahan dan perkalian. Pada kegiatan pembelajaran mengenai permutasi pengantar pembelajaran mengenai pemilihan atau pengambilan beberapa unsur berbeda dari suatu himpunan hingga. Mahasiswa diarahkan untuk memahami cara mengetahui banyaknya pemilihan atau pengambilan yang memerhatikan urutan. Berbeda dengan pembelajaran konsep kombinasi. Pada pembelajaran kombinasi mahasiswa diarahkan untuk mengetahui banyaknya subset yang terdiri dari beberapa unsur dari suatu himpunan hingga yang diberikan.

\subsection{Kegiatan Inti}

Pada tahapan kegiatan inti perkuliahan, desain pembelajaran yang disusun berupa kegiatan diskusi kelompok untuk menyelesaikan permasalahan-permasalahan pencacahan. Permasalahan yang diberikan berupa pertanyaan-pertanyan yang saling terkait satu dengan yang lainnya dengan tujuan menyampaikan konsep yang sedang dipelajari. Masalah yang disuguhkan diawali dengan ilustrasi cerita, kemudian mahasiswa diberikan pertanyaan-pertanyaan secara berurutan (bagian a, b, dan c). Pertanyaan pertama (bagian a.) adalah terkait dengan masalah-masalah yang sederhana dan khusus yang diasumsikan dapat dijawab dan diselesaikan dengan singkat oleh mahasiswa.

Pertanyaan selanjutnya diberikan untuk menjustifikasi jawaban pertanyaan sebelumnya. Mahasiswa diarahkan untuk memberikan argumen akan jawabannya pada bagian a. Setelah memberikan justifikasi, mahasiswa diharapkan dapat memperumum proses menjawab pertanyaan bagian a, sehingga dapat menyelesaikan masalah bagian c. yang merupakan perumuman masalah bagian a. Pada proses diskusi dan pemecahan masalah ini, mahasiswa diarahkan untuk menyelidiki suatu (beberapa) kasus, memberikan argumen untuk meyakinkan jawaban yang diperoleh merupakan solusi yang tepat, dan memperumum temuan secara sistematis.

Untuk mengarahkan mahasiswa menemukan konsep yang benar, proses pembelajaran dilanjutkan pada tahapan diskusi kelas. Pada diskusi ini dua kelompok memaparkan hasil diskusi kelompoknya masing-masing untuk kemudian kelompok lain memberikan tanggapan. Setelah proses diskusi selesai, beberapa mahasiswa diberikan kesempatan untuk mengungkapkan simpulan yang diperoleh masing-masing. Pada akhir kegiatan inti, setiap mahasiswa diarahkan untuk membuat sendiri simpulan mengenai materi pada kegiatan pembelajaran. Berikut adalah contoh lembar diskusi mahasiswa yang telah peneliti susun.

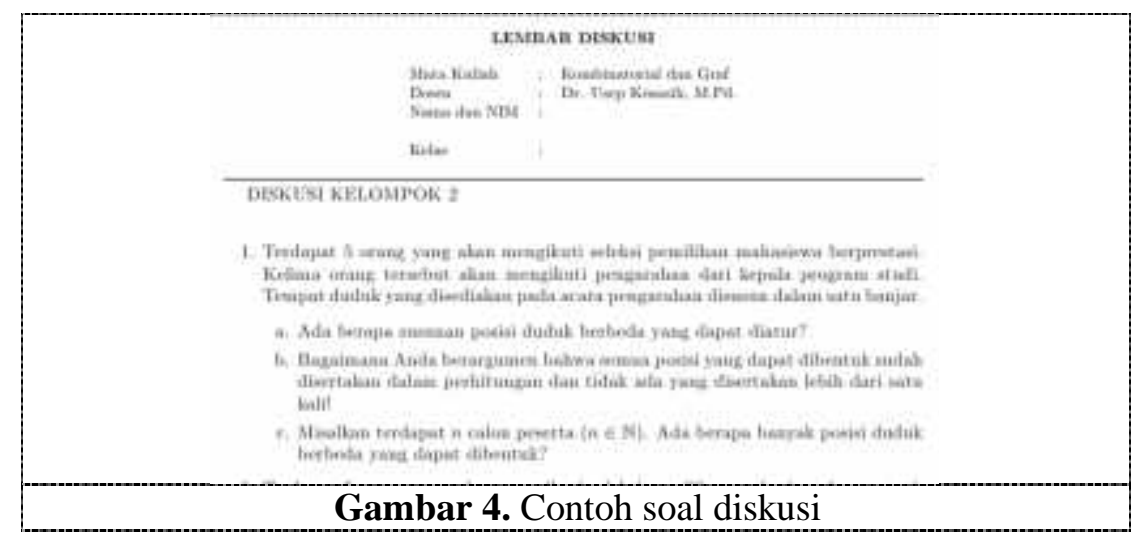

\subsection{Kegiatan Penutup}

Di bagian akhir pembelajaran, diberikan alokasi waktu 15-20 menit bagi setiap mahasiswa untuk mengerjakan soal evaluasi (formatif). Evaluasi tersebut dilaksanakan dengan tujuan mengukur sejauh mana mahasiswa menguasai materi pembelajaran. Lebih jauh evaluasi yang dimaksud 
memiliki tujuan mengetahui sejauh mana penguasaan kemampuan berpikir kombinatorial dari setiap mahasiswa.

Setelah waktu evaluasi berakhir, instruktur menyampaikan soal tugas untuk dikerjakan setiap mahasiswa untuk dikerjakan secara mandiri di luar jam perkuliahan. Terdapat tujuan lain dalam pemberian soal evaluasi yang dalam hal ini bertujuan sama dengan pemberian tugas mandiri. Dengan adanya soal evaluasi dan tugas mandiri, penguasaan kemampuan berpikir kombinatorial level-4 dari setiap mahasiswa dapat diketahui dan diukur oleh peneliti. Hal tersebut dikarenakan baik evaluasi maupun tugas mandiri, soal yang diberikan merupakan soal yang berbeda dengan soal-soal pada diskusi kelompok, namun memiliki penyelesaian yang relatif serupa. Berikut ini adalah contoh lembar soal evaluasi dan tugas yang telah peneliti susun
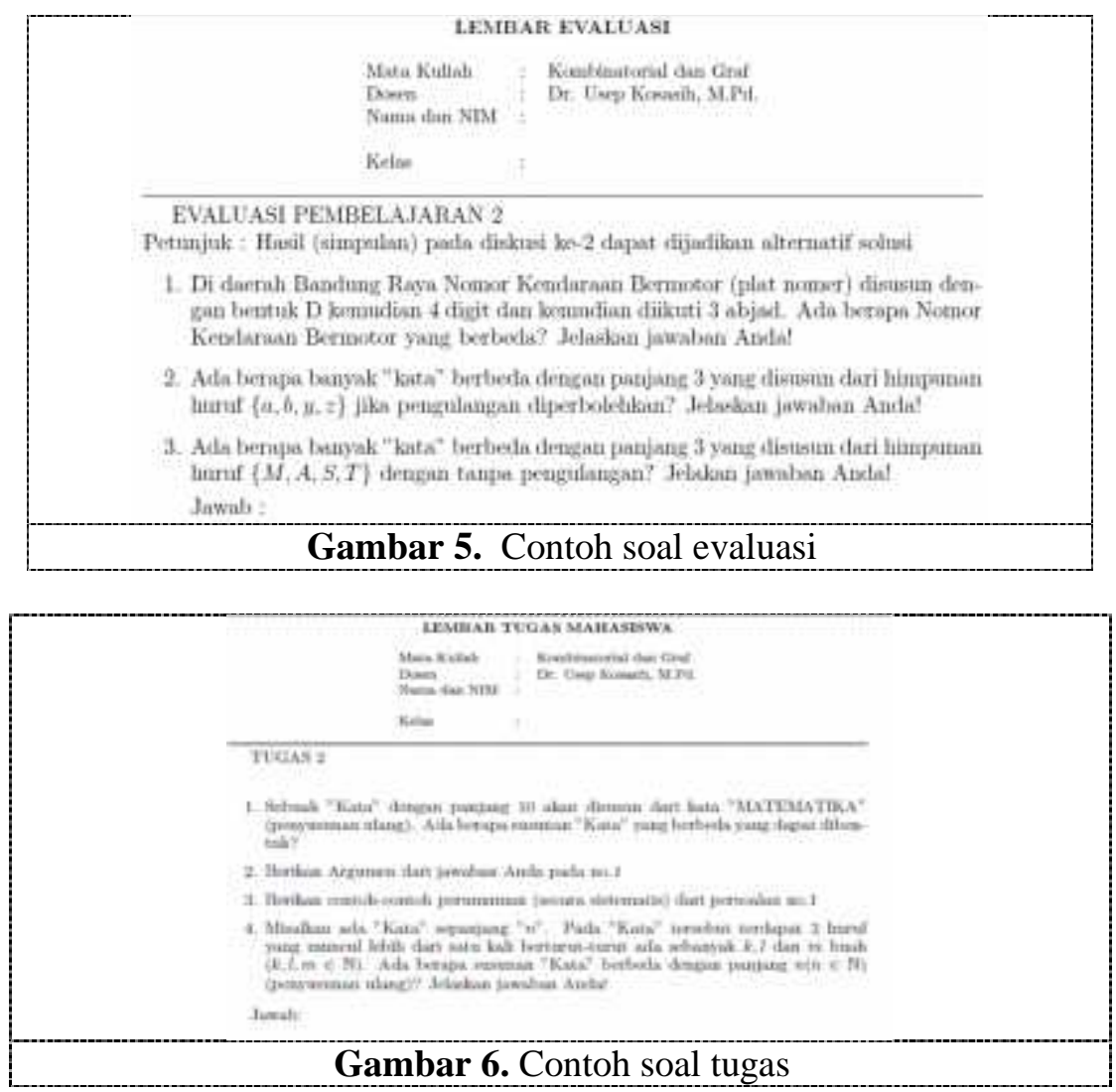

\section{Simpulan dan Saran}

Berdasarkan pembahasan, terdapat beberapa simpulan yang diperoleh dalam penelitian ini. Dalam mengajar mata kuliah KG, khususnya pada bagian materi pencacahan kegiatan diawali dengan review konsep himpunan berhingga yang bersesuaian dengan masing-masing konsep. Kegiatan berlanjut dengan diskusi kelompok yang diperuntukan untuk melatih kemampuan berpikir kombinatorial level 1 sampai 3. Kegiatan selanjutnya adalah diskusi kelas, yakni presentasi beberapa kelompok yang disertai tanya jawab. Kegiatan pembelajaran diakhiri dengan tes mandiri dan pemberian tugas guna mengetahui ketercapaian kemampuan berpikir kombinatorial terutama level 4.

Berdasarkan temuan-temuan dalam penelitian ini, peneliti merekomendasikan beberapa hal yang dapat diteliti lebih lanjut. Bagi peneliti yang tertarik dengan konsep berpikir kombinatorial dapat menelitinya dengan mengaitkan dengan satu atau beberapa kecakapan matematika. Ragam metodologi dapat digunakan dalam mengkaji kemampuan berpikir kombinatorial, salah satunya adalah design research dalam tahapan yang lengkap. Kemudian, peneliti juga merekomendasikan pembahasan berpikir kombinatorial dalam materi-materi yang terkait teori graf. 


\section{Ucapan Terima Kasih (Acknowledgments)}

Peneliti menghaturkan banyak terima kasih kepada seluruh pihak yang telah mendukung dan membantu pelaksanaan penelitian ini terutama Direktorat Riset dan Pengabdian Masyarakat (DRPM), Direktorat Jenderal Penguatan Riset dan Pengembangan, Kemenristekdikti. Penelitian ini dibiayai DRPM melalui hibah Penelitian Dosen Pemula (PDP) sesuai dengan kontrak penelitian tahun anggaran 2018.

\section{Daftar Pustaka}

[1] Ihsan, I.R., dan Kosasih, U. 2017. Analisis kemampuan berpikir kombinatorial mahasiswa pendidikan matematika. Proposal Penelitian : Universitas Islam Nusantara.

[2] Lewy, Zulkardi, dan Aisyah, N. 2009. Pengembangan soal untuk mengukur kemampuan berpikir tingkat tinggi pokok bahasan barisan dan deret bilangan di kelas IX akselerasi SMP Xaverius Maria Palembang. Jurnal Pendidikan Matematika, Volume 3 No. 3: 14-28.

[3] Lockwood, E. 2013. A model of students' combinatorial thinking. Journal of Mathematical Behavior, Volume 32, No 2:251-265.

[4] Rezaie, M, and Gooya, Z. 2011. What do i mean by combinatorial thinking?. Procedia Sosial and Behavioral Science. Volume 11:122 - 126.

[5] Plomp, T. 2013. Educational design research : an introduction. In Plomp, T and Nieveen, N (Eds). Educational design research - part a : an introduction (pp. 10-51). Enschede : Netherlands Institute for Curriculum Development (SLO).

[6] Program Studi Pendidikan Matematika FKIP Uninus. 2016. Dokumen kurikulum program studi pendidikan matematika. Bandung : Universitas Islam Nusantara.

[7] Herman, J., Kučera, R., and Šimša, J. 2003. Counting and configurations, problem in combinatorics, arithmetics, and geometry. Brno : Springer-Verlag.

[8] Bryant, V. 1993. Aspect of combinatorics a wide ranging instruction. Cambridge: Cambridge University Press.

[9] Willis, J. 1996. A framework for task-based learning. Essex: Addison Wesley Longman Limited.

[10] Ihsan, I.R., dan Iskandar, R.S.F. 2015. Model pembelajaran penemuan terbimbing tipe MInDS, suatu alternatif model pembelajran untuk membiasakan peserta didik belajar matematika secara mandiri. Makalah dipresentasikan pada Seminar Nasional Pendidikan Matematika Ahmad Dahlan (Sendikmad), Universitas Ahmad Dahlan, Indonesia. 